\title{
Learning Style and Preferences Among Students and Dentists in Various Dental Colleges of Karachi
}

\author{
Farhan Butt ${ }^{1}$ \\ Marium Iqbal ${ }^{2}$ \\ Khurram Khan ${ }^{3}$
}

\author{
BDS, MAS, MDS \\ BDS, FCPS \\ BDS, MSc
}

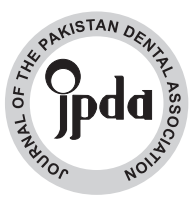

OBJECTIVE: To determine the learning style and learning preference of dental students and dentists in different dental colleges within Karachi.

METHODOLOGY: Total six hundred and four students and dentists participated in this study. Learning preferences were elicited using a Learning Style Questionnaire (LSQ) which consisted of eighty questions. It is based on four learning styles Activist, Theorist, Reflector and Pragmatist. Each of the learning style has twenty related questions in questionnaire. The result was analyzed using Excel software.

RESULTS: The overall response rate was $86.28 \%$. The most preferred learning style was Reflector $(39.73 \%)$ and Pragmatist (35.09\%), while, the least preferred style was Theorist (19.86\%) and Activist (17.71\%). Majority of the students have developed preference for at least one learning style. Some students $(20.52 \%)$ have developed equally strong preference for two learning styles. None of the students have developed equally strong preference for three or four learning styles. CONCLUSION: A wide range of learning occurs in dental Colleges in Karachi. The result of this study can be used to teach students according to their preferred learning style or alternatively, students can be motivated or encouraged to learn in any situation.

KEY WORDS: Learning; learning style; learning preference.

HOW TO CITE: Butt F, Iqbal M, Khan K. Learning style and preferences among students and dentists in various dental colleges of karachi. J Pak Dent Assoc 2018;27(1):27-31.

DOI: https://doi.org/10.25301/JPDA.271.27

Received: 05 November, 2017, Accepted: 04 January, 2018

\section{INTRODUCTION}

$\mathrm{T}$ he concept of knowledge translation can be defined as "Learning that has occurred when students absorb new material, knowledge or the use of a new technique. ${ }^{1,2}$ It is an evolving lifetime process, best achieved through real life experiences. Knowledgeable teachers recognize that students react very differently from one another to the same learning experiences during their period of study in dental colleges. This phenomenon indicates dissimilarities in the students' learning style, also known as "an individual's characteristic", but potentially flexible way of interacting with a learning environment. ${ }^{3}$ Recognizing students' learning individualities may lead to improvement in areas such as designing of a course. ${ }^{4}$ An important strategy used to positively induce students' performance and effective learning

1. Assistant Professor and classified specialist in Periodontics Department, Armed foces institute of dentistry, Rawalpindi.

2. Professor HOD in Operative Dentistry, Endodontics and Paedodontics Department, Jinnah Medical and Dental College.

3. Senior Registrar in Paediatric Dentistry Department. Jinnah Medical and Dental College.

Corresponding author: "Dr. Farhan Butt" < buttfarhan84@ hotmail.com > is by introducing mechanisms that support a variety of learning techniques. ${ }^{5}$

Advances in knowledge translation indicate that awareness of one's own learning style, allows the individual to synthesize information more effectively. ${ }^{6}$ Over the years, adult learning patterns have shifted from a focus on teaching to a focus on learning as directed by educational institutions. ${ }^{7}$ Assessment policies, teaching methods and provisions as well as the practices of learning resources all make an impact on student learning. ${ }^{8}$ An optimum learning environment is produced when factors such as (assessment policies and teaching methods) are combined with different learning style preferences. ${ }^{9,10,11}$ There are a variety of different ways in which students learn. Some prefer presentations from the teacher and others prefer small group discussions. ${ }^{12}$ The ability of a student to learn in the classroom depends on the student's personal capability, preferred learning style and prior preparation, as well as adapting to the instructor's teaching style.

The teaching-learning process is classified according to the various forms of receiving and providing knowledge. Learning style theory has already been utilized in a lot of 
fields such as business education and economics. ${ }^{14,15,16}$ Learning situations can be seen to differ across and within disciplines. Students themselves are unlike in relation to age, gender and phase of education.

Honey and Mumford's Learning Style Questionnaire (LSQ) consists of 80 questions which are intended to measure preferences for learning styles. This questionnaire is built on the earlier work of David Kolb. ${ }^{6}$ This author stated that learning styles mature as a result of inborn factors, prior experiences, and requirements of the surroundings in which the person lives. The LSQ was made commercially available in 1986 for business purpose in the UK. It was later translated to Spanish and was finally adapted for educational purpose. ${ }^{17}$ The LSQ is designed to assess the relative strengths of four different learning styles: Activist, Reflector, Theorist, and Pragmatist.

The activist are those who are enthusiastic for current information, remain up to date, are good presenters and people who do not accept sitting still for a long time or listening to descriptions without interacting. Theorist are people interested in knowing the explanation behind everything. They like clearness in their goals. The reflective style prevails in people who prefer to collect comprehensive facts and information. Reflectors often tend to reproduce and observe upon their inferences before taking action. The pragmatic style is dominated by people who can discover techniques in their daily learning. Pragmatists are curious to discover fresh policies and determine whether these strategies are efficient and valid. Rationale: It is crucial to know the learning preferences of our learners to be able to decide on the teaching methodologies that we as educators plan for them. Although, it may be impossible to revise the whole curriculum it may still be possible to include a few more learning activities or to train the students to adopt new preferences. This can be especially beneficial for an otherwise struggling student who has preferences different from a larger group. Local literature, related to the learning preferences of our students, is deficient. Therefore, it seems appropriate to explore the learning preference of our students from first year through to final year and even after graduation.

\section{METHODOLOGY}

This is a cross-sectional study. Data was collected between 1st January, 2017 and 28th February, 2017 using Honey and Mumford's Learning Style Questionnaire (LSQ). 700 questionnaires were distributed among various dental colleges in Karachi. Students were approached individually, and requested to complete the form. Six hundred and four completed questionnaires were eligible for this study and ninety six were discarded, due to incomplete answers or blank questionnaires. Questionnaires were distributed according to the availability of classes. Each class on average has 45 to 50 students. Students were briefed about the survey. Each student was requested to give consent before participating in this study. No attempt was made to follow up with those students who were absent. It took approximately 20 minutes for each student to complete the questionnaire. Exclusion criteria includes those who did not want to participate in this study or those who were absent. Excel software was used to record and analyze each student's response. Honey and Mumford's scoring norm was used to interpret data from this study. This helped to categorize student's learning preferences. Scoring criteria specially designed for LSQ research, which is available on its website were used for management of data (Table1). Filled questionnaires were kept in locker to which only the researcher had access.

Table 1: learning style interpretation table as presented by Honey and Mumford

\begin{tabular}{|c|c|c|c|c|}
\hline Activist & Reflector & Theorist & Pragmatist & \\
\hline 20 & 20 & 20 & 20 & \multirow{8}{*}{$\begin{array}{l}\text { Very strong } \\
\text { Preference }\end{array}$} \\
\hline \multicolumn{4}{|l|}{19} & \\
\hline 18 & 19 & 19 & 19 & \\
\hline \multicolumn{4}{|l|}{17} & \\
\hline 16 & & 18 & & \\
\hline 15 & & 17 & 18 & \\
\hline \multicolumn{4}{|l|}{14} & \\
\hline 13 & 18 & 16 & 17 & \\
\hline \multirow[t]{2}{*}{12} & 17 & 15 & 16 & \multirow{3}{*}{$\begin{array}{c}\text { Strong } \\
\text { preference }\end{array}$} \\
\hline & 16 & & & \\
\hline 11 & 15 & 14 & 15 & \\
\hline 10 & 14 & 13 & 14 & \multirow{4}{*}{ Moderate } \\
\hline 9 & 13 & 12 & 13 & \\
\hline \multicolumn{4}{|l|}{8} & \\
\hline 7 & 12 & 11 & 12 & \\
\hline 6 & 11 & 10 & 11 & \multirow{3}{*}{ Low preference } \\
\hline 5 & 10 & 9 & 10 & \\
\hline 4 & 9 & 8 & 9 & \\
\hline \multirow[t]{3}{*}{3} & 8 & 7 & 8 & \multirow{9}{*}{$\begin{array}{c}\text { Very low } \\
\text { preference }\end{array}$} \\
\hline & 7 & 6 & 7 & \\
\hline & 6 & 5 & 6 & \\
\hline \multirow[t]{3}{*}{2} & 5 & 4 & 4 & \\
\hline & 4 & 3 & 3 & \\
\hline & 3 & & & \\
\hline \multirow[t]{2}{*}{1} & 2 & 2 & 2 & \\
\hline & 1 & 1 & 1 & \\
\hline 0 & 0 & 0 & 0 & \\
\hline
\end{tabular}

\section{RESULTS}

The sample consisted of 604 respondents, out of which 


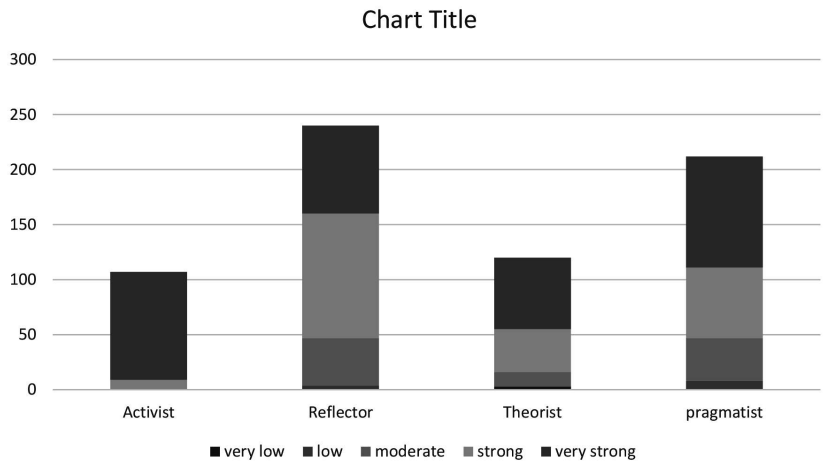

Figure 1: Distribution as percentage of interpretation of the Activist, Reflector, Theorist and pragmatist learning styles among dental students at different dental colleges in Karachi.

482 were dental students $(79.80 \%), 122$ house officers $(20.19 \%)$ and 23 demonstrators $(3.80 \%)$, selected from various dental colleges in Karachi. The sample has 90 first year students (14 male; 76 female), 140 second year students (16 male; 124 female), 120 third year students ( 24 male; 96 female), 132 final year students (32 male; 100 female), 99 house officers (25 male; 74 female) and 23 demonstrators (6 male and 17 female).The demographic data shows that most of the respondents $(69.5 \%)$ are between the age $18-21$ years, while only $30.5 \%$ are between age of 22-33 years, Table 2.

\begin{tabular}{lcc}
\hline & Total & $\%$ \\
Male & 117 & 19.37 \\
Female & 487 & 80.62 \\
Age & & \\
$18-21$ & 420 & 69.53 \\
$22-33$ & 184 & 30.46 \\
\hline
\end{tabular}

Table 2: showing number of male and female in study with their age

The most preferred learning style for first year dental students was pragmatist (41.11\%), Table 3. The least preferred learning style for first year dental students was theorist. It is interesting to note that from second year till final year dental school as well as demonstrator level participants all preferred using the reflector learning style. Activist learning style remained the least preferred method from second year till house job. For demonstrators the least preferred learning style was theorist (13.04\%).

In this study, a variety of learning style preferences was determined when considering individual student's score. Majority of the students have already developed either very strong or strong preference for any one of the four learning styles, Fig. 2. Few students have moderate preference for either learning styles. However, it is interesting to note that only 15 students still have very low or low preference for a specific learning style. Most of the respondents have a preference for one type of learning style, however, out of total 604 respondents $124(20.52 \%)$ respondents have developed equally strong preference for two learning styles.

\begin{tabular}{|c|c|c|c|c|c|c|c|c|c|c|}
\hline \multirow[b]{3}{*}{ Total } & \multicolumn{2}{|c|}{ All } & \multicolumn{2}{|l|}{ Activist } & \multicolumn{2}{|c|}{ Theorist } & \multicolumn{2}{|c|}{ Reflector } & \multicolumn{2}{|c|}{ Pragmatist } \\
\hline & Number & $\%$ & Number & $\%$ & Numb & er $\%$ & Num & ber $\%$ & Number & $\%$ \\
\hline & 604 & 100 & 107 & 17.71 & 120 & 19.86 & 240 & 39.73 & 212 & 35.09 \\
\hline $1^{\text {st }}$ Year & 90 & 14.90 & 20 & 22.22 & 19 & 21.11 & 32 & 35.55 & 37 & 41.11 \\
\hline $2^{\text {nd }}$ Year & 140 & 23.17 & 17 & 12.14 & 29 & 20.71 & 72 & 51.42 & 53 & 37.85 \\
\hline $3^{\text {rd }}$ Year & 120 & 19.86 & 19 & 15.83 & 27 & 22.5 & 56 & 46.66 & 37 & 30.83 \\
\hline $4^{\text {th }}$ Year & 132 & 21.85 & 26 & 19.69 & 29 & 21.96 & 61 & 46.21 & 47 & 35.60 \\
\hline House officer & r 99 & 16.39 & 17 & 17.17 & 25 & 25.35 & 57 & 57.57 & 25 & 25.25 \\
\hline Demonstrator & or 23 & 3.80 & 4 & 17.39 & 3 & 13.04 & 11 & 47.82 & 8 & 34.78 \\
\hline
\end{tabular}

Table 3: Descriptive statistics of all respondents of BDS.

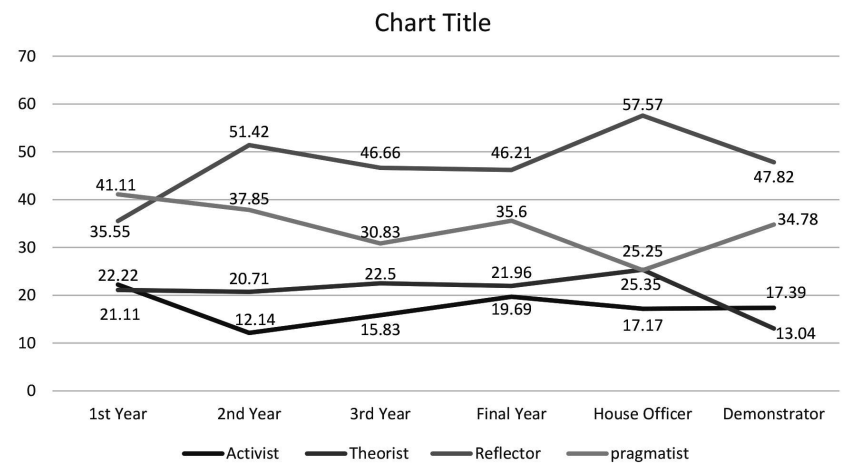

Figure 2: Showing change in percentage in learning styles from First year till Demonstrator

\begin{tabular}{|l|c|c|c|c|}
\hline \multirow{2}{*}{ Preference } & \multicolumn{4}{|l|}{$\begin{array}{l}\text { Number of students with particular learning style } \\
\text { preference }\end{array}$} \\
\cline { 2 - 5 } & Activist & Reflector & Theorist & Pragmatist \\
\hline Very strong & 98 & 80 & 65 & 101 \\
\hline Strong & 8 & 113 & 39 & 64 \\
\hline Moderate & 1 & 43 & 13 & 39 \\
\hline Low & & 4 & & 8 \\
\hline Very low & & & 3 & \\
\hline
\end{tabular}

Table 4: Summary of learning style preferences for BDS students

While, none of the respondents have equally strong preference for more than two learning styles. 


\section{DISCUSSION}

This research allows us to examine the learning styles of students and demonstrators in various Dental colleges in Karachi, Pakistan. Individuals have different preferences in the way they absorb and process information, which leads to different learning styles.

In our study the most preferred learning style was Reflector and least preferred was Activist. A similar study was conducted by Alexandra I et al., on students of pharmacy using the same LSQ questionnaire. He concluded that most participants preferred the pragmatist learning style, and the least preferred learning style was theorist. ${ }^{18}$ In another study conducted to see differences in learning style based on gender, it was found that, preferences for male and female students are not significantly different. ${ }^{19}$ Wilkinson conducted a study on first year medical and dental students and did not find any effect of student's preferred learning style on their result/ scores. ${ }^{20}$ In another study it was found that those students who had a predominating "activist" learning style have showed weakest performance in the subject of anatomy. ${ }^{21}$

Moreover, the stability of learning style of student remains ambiguous during their learning period. ${ }^{15}$ Conflicting results have been found in research between years of study and learning style preferences. It is still unsure if the learning style/ preferences remain stable over a period of time and if it changes, which factors contribute to its change. Since some studies revealed that there was a change with time and yet others said that there was no change, so we need to explore it further In one of the study conducted by Randall LE found no relationship between years of study and learning style preference. ${ }^{22}$ While in another study, it was found that dissimilarities in learning style preference occur and that these preferences change over time, which may be linked to the personal maturing of students. ${ }^{23}$ Lecturers also differ in their methods, style of teaching and/or delivering lectures. When the learning style of the student is not well-matched with the teaching style of the lecturer, difficulties in educational accomplishments may occur. Classroom conflicts may occur when teaching and assessment methods do not match the various learning styles of students. Factors such as classroom environment, past educational background, inspiration, gender and multiethnic issues additionally influence the learning process. ${ }^{17}$ Randall et al. in 1995 suggested an advantage in teaching styles which fit a broader range of students. Students may benefit by gradually introducing class activities that significantly expand their learning style preferences. In this way students can be assisted in broadening their abilities to accommodate greater variety. ${ }^{22}$ In another study conducted by Witkin et al. 1976 results suggest that, teachers recognized the various learning styles of students. ${ }^{23}$ This will provide a catalyst for appraising the learning situation and will ultimately result in improvements and success of learners through better matched learning activities. In another study conducted on dental students, the authors used a different learning style questionnaire based on sensory inputs. They have not introduced anything so far about the new strategies introduced. ${ }^{24}$

In students with same learning style, preference can still be found, which can be mild, moderate or strong. This explains the difference among students with similar learning styles. Some factors that differentiate individual learning styles include experience, skillfulness and knowledge.17 When students are familiar regarding their own learning style (most prevalent), then, they can also work to adapt to less prevalent learning styles. ${ }^{25}$

It can be concluded that, faculty should learn to apply various teaching strategies to reach more students in a specified class, thus inspiring all the students to learn from teaching activities. ${ }^{23}$ However, the point is not to match the teachers teaching style with the student's learning style, rather, to achieve a balance by confirming that each style is met at reasonable level as part of the teaching method. ${ }^{26,27}$

\section{CONCLUSION}

The overall findings suggests that teaching mechanisms used within Dental schools should support a broad range of learning styles. It is important for learners to practice a variety of learning styles because each style has its own strengths and weaknesses depending on the situation. Activist and theorist were the least preferred learning style, which indicates, the need for modification to teaching-learning process, so that the students can develop these processess more easily.

\section{LIMITATIONS}

Our study was cross-sectional, which prevents conclusion regarding changes in learning style over period of time. In future, more studies should be performed to identify students' learning style at the time of entrance in Bachelor of Dental Surgery program, particularly longitudinal studies to observe changes in learning preferences over time.

\section{CONFLICT OF INTEREST}

None declard

\section{REFERENCES}

1. Diaz DP, Bontenbal KF. Learner preferences: Developing a learner-centered environment in the online or mediated 
classroom. Ed at a Distance. 2001; 15(8):69-78. 2. Davidman L. Learning style: The myth, the panacea, the wisdom. The Phi Delta Kappan. 1981 ; 62(9):641-5. 3. Butler KA. How kids learn: What theorists say. Learning. 1988;17(4):30-4.

4. Lowery CA. Adapting to student learning styles in a first year electrical/electronic engineering degree module. Engineering education. 2009 Jun 1; 4(1):52-60. 5. Trigwell K, Prosser M, Ginns P. Phenomenographic pedagogy and a revised approaches to teaching inventory. Higher Edu Res Dev. 2005; 24(4):349-60.

https://doi.org/10.1080/07294360500284730

6. Geertshuis SA, Fazey JA. Approaches to learning in the workplace. J workplace learn. $2006 ; 18(1): 55-65$. https://doi.org/10.1108/13665620610641319

7. Wisker G, Brown S. Enabling student learning: Systems and strategies. Psychology Press; 1996.

8. Watters JJ, Ginns IS. Developing motivation to teach elementary science: Effect of collaborative and authentic learning practices in preservice education. J Sci Teacher Educ. 2000; 11(4):301-21.

https://doi.org/10.1023/A:1009429131064

9. Lyons-Lawrence CL. Effect of learning style on performance in using computer-based instruction in office systems. Delta Pi Epsilon Journal. 1994; 36(3):166. 10. Pinto, J.K., M.A. Marshall, and E.J. Bayle. 1994. A three-year longitudinal study of changes in student learning styles. J Coll Student Dev 35, no. 2: 113-9

11. Mainemelis C, Boyatzis RE, Kolb DA. Learning styles and adaptive flexibility testing experiential learning theory. Management learning. 2002; 33(1):5-33. https://doi.org/10.1177/1350507602331001

12. Busato VV, Prins FJ, Elshout JJ, Hamaker C. Learning styles: a cross-sectional and longitudinal study in higher education. Brit J Edu Psychol. 1998; 68(3):427-41. https://doi.org/10.1111/j.2044-8279.1998.tb01302.x 13. Marriott P. A longitudinal study of undergraduate accounting students' learning style preferences at two UK universities. Account Educ. 2002 ; 11(1):43-62.

https://doi.org/10.1080/09639280210153263

14. Felder RM, Silverman LK. Learning and teaching styles in engineering education. Eng Educ. 1988; 78(7):674-81. 15. Kolb AY, Kolb DA. Learning styles and learning spaces:
Enhancing experiential learning in higher education. Acad manage learn edu. 2005;4(2):193-212.

https://doi.org/10.5465/AMLE.2005.17268566

16. Honey P, Mumford A. Using your learning styles. Maidenhead: Peter Honey; 1986.

17. Feldman J, Monteserin A, Amandi A. Detecting students' perception style by using games. Camput Educ. 2014; 71:1422.

https://doi.org/10.1016/j.compedu.2013.09.007

18. Czepula AI, Bottacin WE, Hipólito Jr E, Baptista DR, Pontarolo R, Correr CJ. Predominant learning styles among pharmacy students at the Federal University of Paraná,

Brazil. Pharmacy Practice (Granada). 2016; 14(1):0-.

19. McKeachie WJ. Learning styles can become learning strategies. Natl Teach Learn Forum. 1995;4:1-3.

20. Wilkinson T, Boohan M, Stevenson M. Does learning style influence academic performance in different forms of assessment?. J Anat. 2014;224(3):304-8.

https://doi.org/10.1111/joa.12126

21. O'Mahony SM, Sbayeh A, Horgan M, O'Flynn S, O'Tuathaigh CM. Association between learning style preferences and anatomy assessment outcomes in graduateentry and undergraduate medical students. Anat Sci Educ. 2016;9(4):391-9.

https://doi.org/10.1002/ase.1600

22. Randall LE. Learning Style Preferences of Physical Education Majors: Implications for Teaching and Learning. J Excell Coll Educ. 1995; 6(2):57-77.

23. Witkin HA, Moore CA, Goodenough DR, Cox PW. Field-dependent and field?independent cognitive styles and their educational implications. ETS Research Report Series. 1975; 1975(2):1-64.

https://doi.org/10.1002/j.2333-8504.1975.tb01065.x

24. Iqbal M, Zaman L. Learning Style Preferences of Dental Students, Karachi. Med Forum 2015;26(9):17-20 25. Felder RM. Are learning styles invalid? (Hint: No!). On-course newsletter. 2010:1-7.

26. Felder RM, Brent R. Understanding student differences. JJ Eng Educ. 2005; 94(1):57-72.

https://doi.org/10.1002/j.2168-9830.2005.tb00829.x

27. Felder RM. Matters of style. ASEE prism. 1996; 6(4):1823. 